\title{
Studies on zooplankton of Lago Paione Superiore
}

\author{
Marina MANCA* and Patrizia COMOLI \\ CNR Istituto Italiano di Idrobiologia, L.go V. Tonolli 50, 28922 Verbania Pallanza, Italy \\ *e-mail corresponding author: m.manca@iii.to.cnr.it
}

\begin{abstract}
We report here the results of a three year study on the zooplankton of Lago Paione Superiore, an acid sensitive lake above the tree line in the Italian Alps. The research was carried out within MOLAR, an EC-founded Project on "Measuring and Modeling the dynamic response of remote mountain lakes ecosystems to environmental change". This study comes after a series of investigations on the effects of acidification, in which we documented the changes occurred with decreasing water pHs, by comparing the recent situation with that in the literature of the 40s, and reconstructed the beginning of anthropogenic disturbance through an analysis of the past cladocera assemblages archived in the lake sediments. A characteristic pattern in seasonal periodicity is a transition from a community dominated by small zooplankton (August) to a community where the large particle-feeder Daphnia longispina dominates. This is a typical pattern observed in fishless, copepod-cladocera lakes. Regardless from which food is able to exploit, Daphnia population of Lago Paione Superiore is composed by well-fed organisms, visually rich in lipids, able to produce more than one generation/year of parthenogenetic females at density levels which are rather high in an oligotrophic high mountain lake.
\end{abstract}

Key words: zooplankton, trophic web, acidification, high mountain lakes

\section{INTRODUCTION}

Being located in remote areas, alpine lakes are good indicators of regional and global pollution transmitted by air. Extreme environmental conditions and very low nutrient concentrations lead to very simplified biological communities, making these sites suitable for studies on basic limnology (Tilzer 1973; Tilzer \& Schwartz 1976; de Bernardi et al. 1983; Capblancq \& Laville 1983; Fott et al. 1994).

From 1992 onward, within a series of international projects on acidification of alpine lakes, also financially supported by the EU, studies on zooplankton have been performed in various sites in the Italian Alps, and particularly on the three Paione lakes (Pennine Alps, Val Bognanco). Information on the plankton of these lakes was available since the middle of the 40s (Tonolli 1949, Tonolli \& Tonolli 1951), so that the changes in species composition and population density with acidification have been outlined (Cammarano \& Manca 1997). More recently, Lago Paione Superiore has been selected as the site in the Italian Alps for studying and modelling the dynamic response of high mountain aquatic ecosystems to environmental change in the framework of a three year project partially funded by the EC (MOLAR Project). The present paper reports the results obtained on zooplankton in the period 1996-1998 within this project. Detailed information on the basic features of the lake (geographic and morphometric parameters) as well as on seasonal changes in water chemistry and temperature is reported in the paper by The MOLAR Water Chemistry Group (1999, this issue), where the long-term trends in hydrochemistry are also discussed.

\section{MATERIAL AND METHODS}

We collected zooplankton at $c a$ monthly intervals during the ice-free period, namely from July to October in the years 1996, 1997 and 1998. According to the MOLAR sampling protocol (Fott 1996; Straškrabová et al. 1999, this issue), on each date we collected four quantitative samples, at the same site, corresponding to the point of maximum depth $(11.7 \mathrm{~m})$. Two of them were integrated samples from the surface to the bottom collected with an Apstein type plankton net of $200 \mu \mathrm{m}$ mesh size towed to filter $\mathrm{ca} 1 \mathrm{~m}^{3}$ of water. Of the two, one was fixed in $4 \%$ formaldehyde, the other was maintained cold, to keep the animals alive, until reaching the laboratory in Pallanza. Here it was immediately concentrated on pre-weighted nylon circles $(40 \mu \mathrm{m}$ mesh size), to be dried in an oven $\left(60{ }^{\circ} \mathrm{C}\right.$, overnight $)$, and used for measuring dry weight on an electronic microbalance. During the first year of research, we also measured the carbon content of the dried samples, by using a CHN Elemental Analyzer (Carlo Erba, ANA 1500). In addition to the net integrated samples, we also collected volumetric ones (10 1 each, with a Ruttner bottle), at $1 \mathrm{~m}$ depth and at $1 \mathrm{~m}$ above the bottom. We analyzed the latter in $10 \mathrm{ml}$ Utermöhl chambers on an inverted microscope, after concentration on $40 \mu \mathrm{m}$ nylon net filter. These two samples gave us abundance and body size of the smaller zooplankters (nauplii and copepodites of copepods, as well as rotifers), which were not retained by the Apstein net. In most cases, we counted the samples entirely, recording the different taxa and developmental stages, eggs included. We converted body length of copepodites and adults of copepods into 
individual biomass (carbon) by applying published Length/Weight Regression Equations (Mc Cauley 1984), following recommendations by Bird \& Prairie (1985), and taking carbon $=0.5 \mathrm{~d} . \mathrm{w}$. To estimate carbon of Daphnia we used our original Length/Carbon Regression Equation obtained from direct carbon measurements of pre-measured live specimens (Manca et al. 1997). Biovolume of nauplii was obtained from body length (a) by applying the formula $\mathrm{BV}=0.217 \mathrm{a}^{3}$. For rotifers we applied the formulas reported in Mc Cauley (1984). Individual estimates of biovolume were converted into carbon biomass taking carbon $(\mathrm{mg})=0.05$ $\mathrm{BV}\left(\mathrm{mm}^{3}\right)$.

\section{RESULTS AND DISCUSSION}

Lago Paione Superiore is a typical Daphnia-Cyclops lake, where, during the ice-free season, the population of the copepod starts to develop earlier than that of the cladoceran (Fig. 1). This is clear from the seasonal changes in numbers of 1997 , where also we probably missed the peak of Daphnia population. Maximum densities, as well as their timing, largely vary from year to year, probably reflecting differences in meteorological conditions and in the time of ice melting. In most net samples, we only found the two species Daphnia longispina and Cyclops abyssorum tatricus. Occasionally, other species, usually inhabiting the littoral zone, namely Eucyclops serrulatus, became important, probably as a result of the action of wind.

Nauplii are usually most abundant in August: a second phase of naupliar development can also take place later in the season, in October (1998) (Fig. 2). During 1996 there was a nice transition from nauplii to copepodites and to adults, also accompanied by a decrease in the attained total population density. The two conditions allowed us the calculation of the production of the population by means of the Allen graphical method.

Apart from 1996, when values were exceptionally high, Daphnia population density is at a maximum of 10 ind $1^{-1}$, a value not expected in an oligotrophic high mountain lake (Fig. 3). Parthenogenetic females appear earlier than males, and usually do not reach the levels of abundance of the latter ones. Egg-bearing females are very scarce in the samples, probably also because of the method of collection and fixation used. In a previous study, ovigerous females were present in sufficient numbers to allow us the reconstruction of a size specific clutch size (Cammarano \& Manca 1997). In that study, we found ovigerous females with a maximum of 12 eggs in the brood pouch and we discussed the possible role of Cyclops in determining the large variability in fecundity of females of the same size.

This type of analysis is of great interest in DaphniaCyclops systems: eggs can be an important food source for copepodites of Cyclops. The latter are thought to be unable to complete their development without using this food source (Gliwicz 1994). Apparently, the partheno- genetic females of Lago Paione Superiore are smaller than those found infested by copepodites by other authors. However, other factors than size can also influence vulnerability to copepodites' attack (Hanazato \& Dodson 1995).

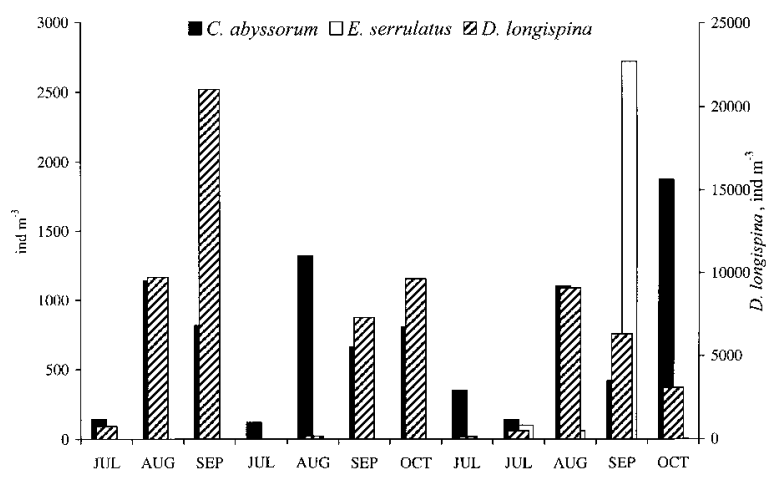

Fig. 1. Seasonal changes in numbers of crustacean zooplankton of Lago Paione Superiore during the ice-free period, 19961998.

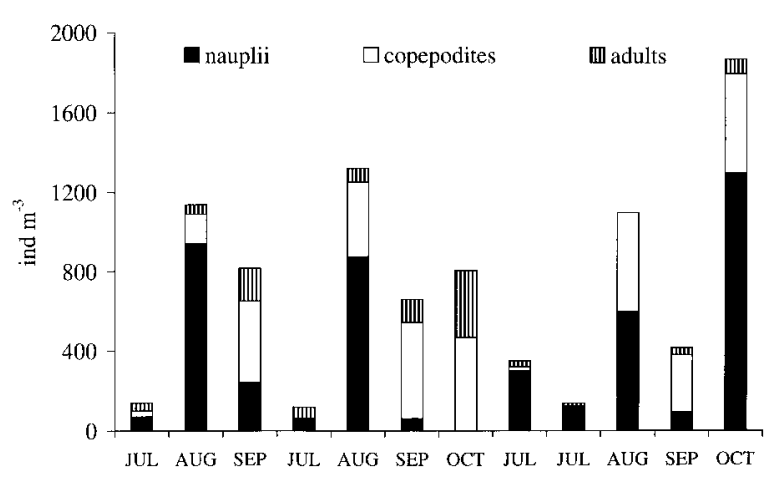

Fig. 2. Population structure of $C$. abyssorum tatricus in Lago Paione Superiore, during the ice-free period, 1996-1998.

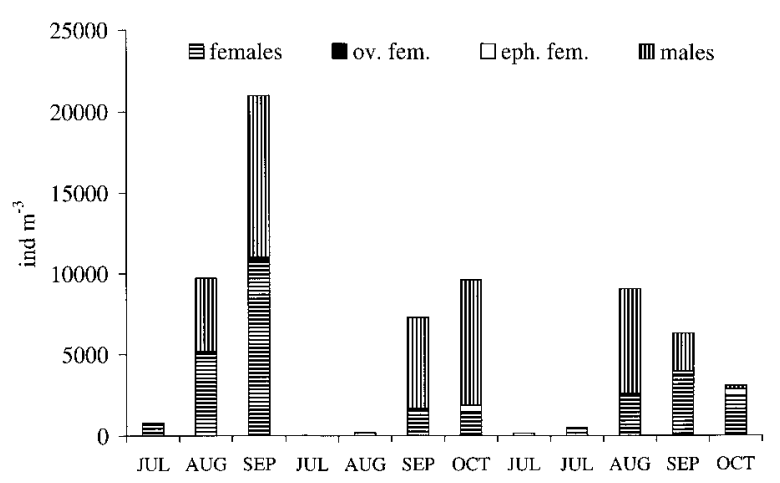

Fig. 3. Population structure of D. longispina in Lago Paione Superiore during the ice-free period, 1996-1998.

On the other hand, the earlier development of nauplii, which are competitively inferior with respect to Daphnia, allows the survivorship of their population (Santher 1993). 
The dominance of Daphnia is of course more pronounced when we consider biomass, instead of numbers (Fig. 4). Apart from the situation of August 1997, the role of copepods is marginal. Values of about $50 \mathrm{mg} \mathrm{m}^{-3}$ of carbon are stored in this part of the pelagic food web, although occasionally, the value can double (September 1996). This amount is, to a large extent, stored in parthenogenetic females, which, at their ambient temperatures can lay eggs every ten days (Vijverberg 1989). Therefore, in this lake they make up most of the total production of the zooplankton.

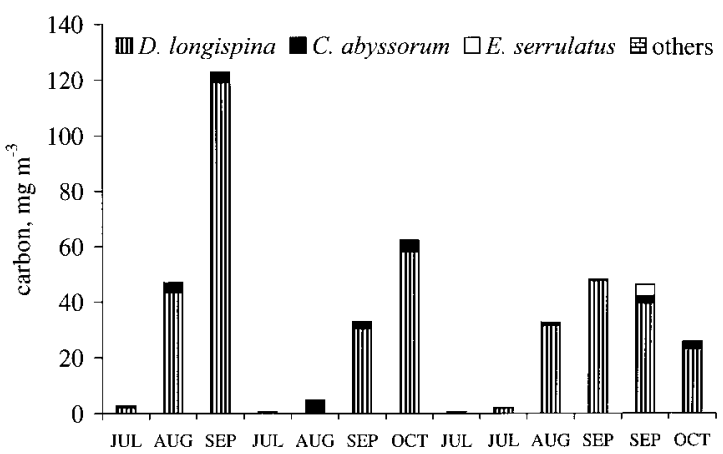

Fig. 4. Standing stock biomass (carbon) of crustacean zooplankton in Lago Paione Superiore, during the ice-free period, 1996-1998.

Along with the season, the individual carbon content of Daphnia increases (Fig. 5); while earlier in the summer a large proportion of carbon is probably stored in eggs, to allow the reaching of the peak in population density, later on, carbon is stored in fewer, older and larger sized females, which reproduce at a lower rate.

As expected, zooplankton numbers are negligible in the uppermost water layer (Fig. 6). As typical for alpine lakes, during the day zooplankton swims close to the bottom in Lago Paione Superiore, to minimize the damage from UV radiation and the energy expenditure for DNA repair (Hessen 1994). This heterogeneous vertical distribution reflects the dominance of crustacean zooplankton, but it is maintained also when rotifers (mainly Keratella quadrata) dominate (September 1996). The mean levels of abundance attained are noteworthy ( $\mathrm{ca}$ 20 ind $\mathrm{l}^{-1}$ on average). Maximum values, found in August, largely vary among the years; up to $50{\text { ind } 1^{-1}}^{-1}$ can be reached. This extreme variability can result from the type of sampling (volumetric sampling on a single location), which makes it possible to collect swarms. A large spatial variability (both horizontal and vertical) characterizes the distribution of zooplankton in this type of environments. Except for one date, Cladocera, and particularly Daphnia (D. longispina) are the most abundant organisms, especially in September. They usually develop after Cyclops abyssorum, which peaks in August. The dominance of cladocera is amplified by the transformation of data into biomass (carbon) (Fig. 7). In total, copepods and rotifers reach values below $10 \mathrm{mg}$ $\mathrm{m}^{-3}$, whereas cladocera (D. longispina) can reach levels 25 times higher than those (September, 1998). In August, small organisms (nauplii of copepods as well as rotifers) are most abundant, or dominant (Fig. 8). The earlier development of nauplii with respect to cladocera, has been regarded as a strategy of Cyclops for surviving in the presence of Daphnia, the efficient particle-feeder and the strongest competitor (Santher 1993). In Lago Paione Superiore, the contribution of small organisms to the total standing stock biomass (carbon) is at the limit of the detection of the method used for the calculation $\left(<4 \mathrm{mg} \mathrm{m}^{-3}\right.$ ) (Fig. 9).

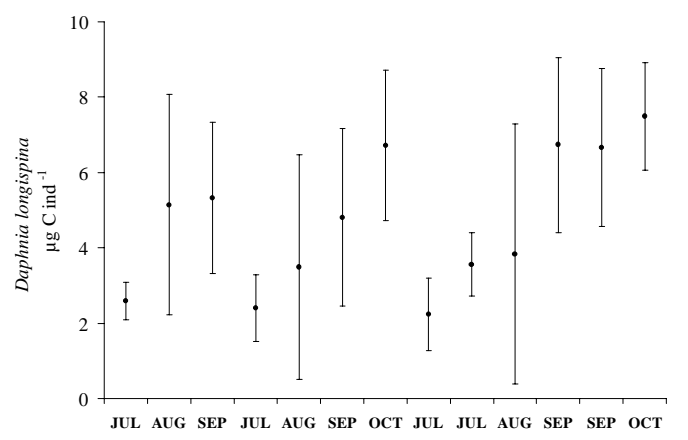

Fig. 5. Individual carbon biomass of $D$. longispina (average, \pm s.d.) in net samples collected on each date.

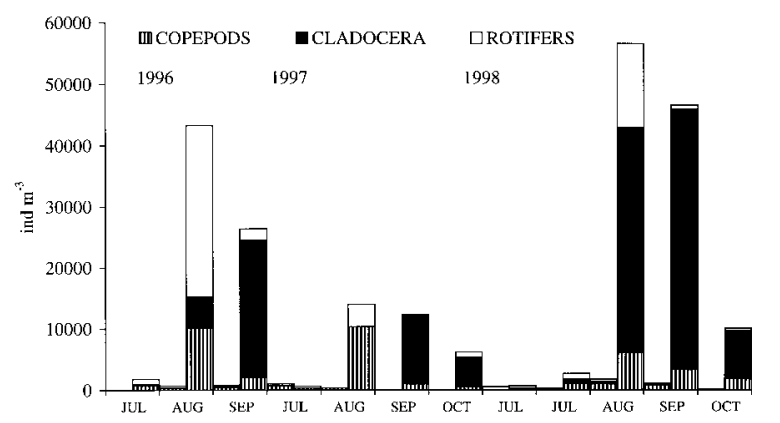

Fig. 6. Abundance of zooplankton in volumetric samples: on each month, the left columns refer to the surface and the right ones to the bottom.

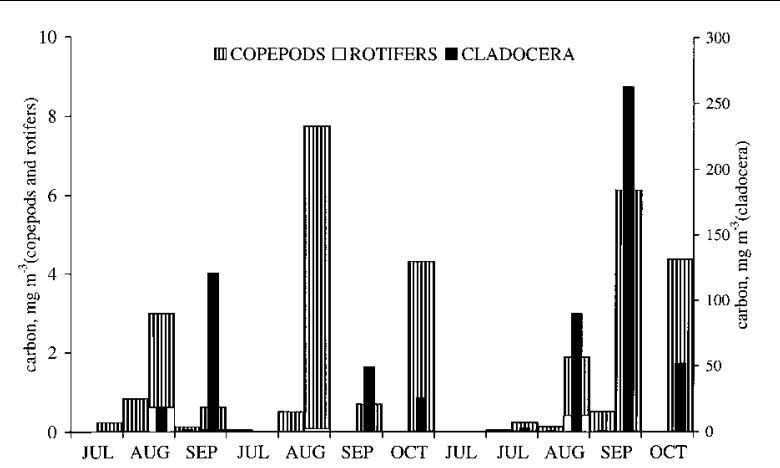

Fig. 7. Standing stock biomass (carbon) of the zooplankton of Lago Paione Superiore in the volumetric samples for the period 1996-1998. On each month, the left bars refer to the surface sample, and the right ones to the bottom sample. 


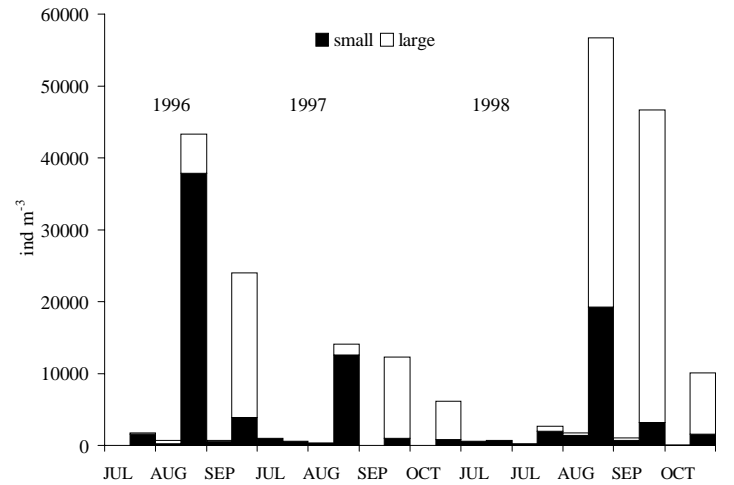

Fig. 8. Abundance of small (copepod nauplii and rotifers) and large (adults and copepodites of Cyclops, and Daphnia) zooplankton in volumetric samples of Lago Paione Superiore. On each month, left bars refer to the surface samples, and right ones to the bottom samples.

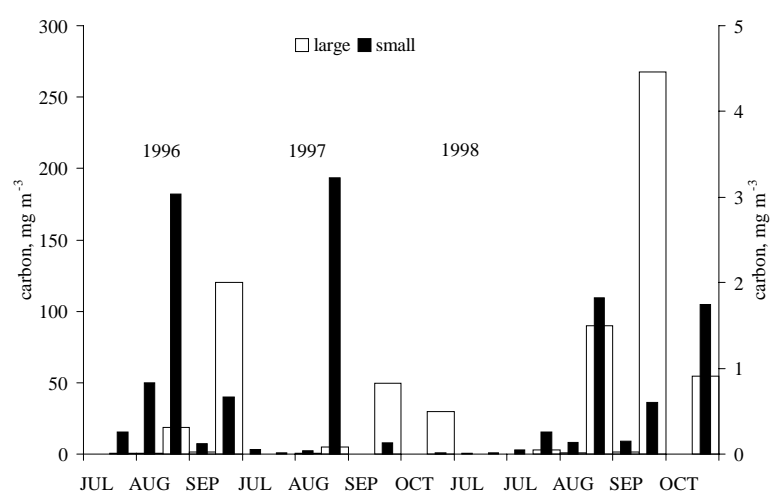

Fig. 9. Standing stock biomass (carbon) of small (copepod nauplii and rotifer) and large (Cyclops, adults and copepodites, and Daphnia) zooplankton in volumetric samples of Lago Paione Superiore. On each month, left bars refer to the surface samples, and right ones to the bottom samples.

There is a very good correspondence between the data of carbon biomass obtained directly from dry weight of live samples and those obtained indirectly, by applying length-weight regression equations (LWRE) to the original measurements (Fig. 10). The correspondence is striking, especially if we take into account that the estimates come from independent samples, where a large variability was expected. Only in one occasion the measured biomass seems to be underestimated, because of the loss of material from the filter.

The dominance of Daphnia specimens as well their richness in lipids (lipid index usually around 4; Goulden \& Hornig, 1981) means that food is of good quality. Which are the food sources for Daphnia is an open question. Certainly, it is intriguing the correspondence, already stressed and published (Cammarano \& Manca 1997), between the decline in phytoplankton numbers and the increase in Daphnia population density. This is still the case when we plot the carbon biomass of microorganisms versus that of zooplankton (Fig. 11) as widely described in Callieri et al. (1999, this issue).

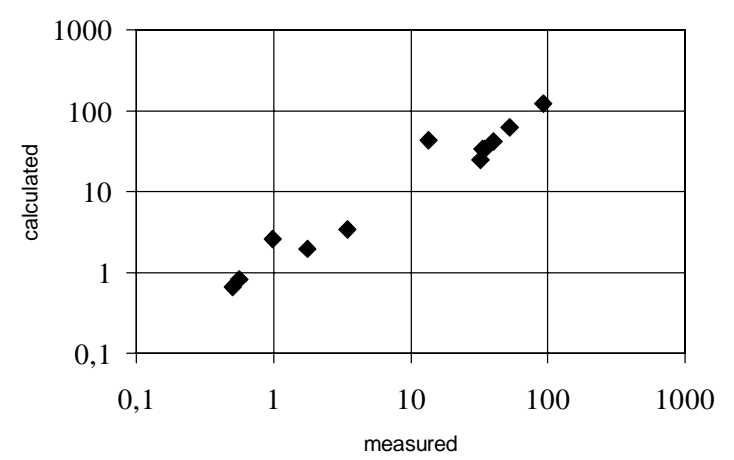

Fig. 10. Comparison of measured/calculated carbon content of net zooplankton from Lago Paione Superiore, during the study period.

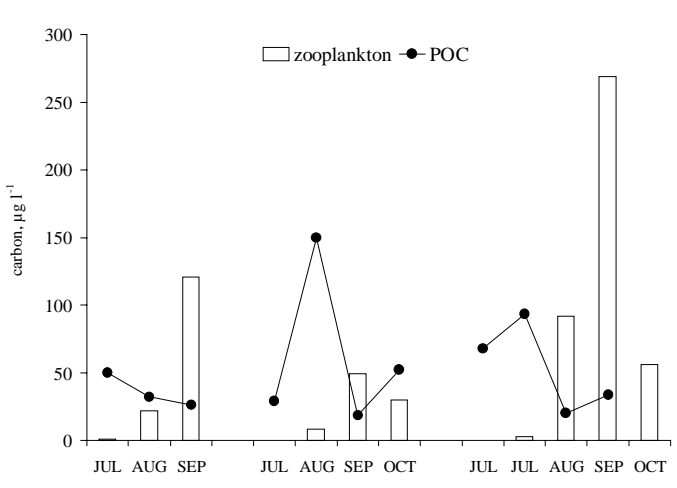

Fig. 11. Standing stock carbon biomass of zooplankton and carbon content of microorganisms (phytoplankton + protozoa + bacteria) in volumetric samples (bottom) of Lago Paione Superiore, during 1996-1998, ice-free period.

\section{CONCLUSIONS}

As a result of a three year research, we are able to identify some interesting traits of the zooplankton of Lago Paione Superiore. Despite the large inter-annual variability, we can basically recognize a transition from a community dominated by small zooplankton (August), to a community where the large particle-feeder D. longispina dominates (September). This is the typical pattern observed in copepod-cladocera lakes where planktivorous fish are absent. Whether or not this transition can be even partly responsible for possible changes in biomass or numbers of the other components of the pelagic food web is an open question. Data on the vertical distribution, although only on two extreme zones (bottom/surface) give an indication of what was largely expected, i.e. the benthic habit of Daphnia during the day. We do not have direct evidence on Lago Paione Superiore, but knowing literature on daily vertical migrations of Daphnia, we can expect the same impact along the water column. Even changes in phytoplankton or other organisms within the surface layer may be explained by the result of a nocturnal feeding of this large and efficient particle feeder. Regardless on which food it is able to exploit in Lago Paione Superiore, D. longispina population is composed by well-fed organisms, visually 
rich in lipids and able to produce parthenogenetic eggs in high numbers, to allow the production of more than one generation/year of parthenogenetic females, at high densities. After ice melting, when food is abundant, the few individuals present store carbon and energy into egg production; the small females born from these parthenogenetic eggs reproduce relatively fast. When food decreases, the fewer, aging individuals become larger, so increasing their ability to exploit resources, mainly devoted to produce males and resting eggs, to allow the survivorship of the population during the ice-cover phase.

Males are even more abundant than females, especially during the last year. We hope this is not a sign of an anthropogenic alteration in this extremely delicate environment; evidence on this comes from a palaeolimnological study (Guilizzoni et al. 1996).

\section{ACKNOWLEDGMENTS}

We are very indebted to Dr Jan Fott for commenting the manuscript.

\section{REFERENCES}

Bird, D.F. \& Y.T. Prairie 1985. Practical guidelines for the use of zooplankton length-weight regression equations. $J$. Plankton Res., 7: 955-970.

Callieri, C., A. Pugnetti \& M. Manca. 1999. Carbon partitioning in the food web of a high mountain lake: from bacteria to zooplankton. In: Straškrabová, V., C. Callieri \& J Fott (Eds), Pelagic food web in mountain lakes. MOuntain LAkes Research Program. J. Limnol., 58(2): 144-151.

Cammarano, P. \& M. Manca. 1997. Studies on zooplankton in two acidified high mountain lakes in the Alps. Hydrobiologia, 356: 9-109.

Capblancq, J. \& H. Laville 1983. Le Lac de Port-Bielh (Pyrénées): exemple de fonctionnement d'un écosistème lacustre de haute montagne. In: Lamotte M. \& F. Bourlière (Eds), Structure et fonctionnement des écosystèmes limniques, Masson: 51-79.

de Bernardi, R., M. Brogi \& I. Origgi. 1983. Dinamica di popolazione e produzione di Arctodiaptomus alpinus in due laghi alpini d'alta quota: Laghi Boden, Alta Val Formazza, m 2340 s.l.m. Atti $5^{\circ}$ Congresso A.I.O.L.: 407-416.

Fott J., M. Prazáková, E. Stuchlík \& Z. Stuchlícová. 1994. Acidification of lakes in Šmava (Bohemia) and in the High Tatra Mountains (Slovakia). Hydrobiologia, 274: 3747.

Fott, J. 1996. Methods of sampling of zooplankton. In: MOLAR Protocol: 6pp.

Gliwicz, Z.M. 1994. Retarded growth of cladoceran zooplankton in the presence of a copepod predator. Oecologia, 97: 458-461.
Goulden L.E. \& L.L. Hornig. 1981. Population oscillations and energy reserves in planktonic cladocera and their consequences to competition. Proc. Natl. Acad. Sci. USA, 77: 1716-1720.

Guilizzoni, P.A. Marchetto, A. Lami, N.G. Cameron, P.G. Appleby, N.L. Rose, Ø.A. Schnell, C.A. Belis, A. Giorgis \& L. Guzzi. 1996. The environmental history of a mountain lake (Lago Paione Superiore, Central Alps, Italy) for the last c. 100 years: A multidisciplinary paleolimnological study. J. Paleolimnol., 15: 245-264.

Hanazato, T. \& S.I. Dodson. 1995. Morphological defences of Daphnia against copepod predation on eggs. Arch. Hydrobiol., 133: 49-59.

Hessen, D.O. 1994. Daphnia responses to UV-light. Arch Hydrobiol. Beih., 43: 185-195.

Manca, M., P. Comoli \& T. Spagnuolo. 1997. Length-specific carbon content of the Daphnia population in a large subalpine lake, Lago Maggiore (Northern Italy): the importance of seasonality. Aquat. Sci., 59: 48-56.

Manca, M., P. Comoli \& V. Lencioni. 1999. Population dynamics and production of crustacean zooplankton in two mountain lakes in the Italian Alps (Lake Paione Superiore and Lake Malghette). J. Limnol., 58(1): 25-28.

McCauley, E. 1984. The estimation of the abundance and biomass of zooplankton in samples. In: Downing J.A. \& F.H. Rigler (Ed.), A Manual on Methods for Assessment of Secondary Productivity in Freshwaters. Blackwell Scientific Publications: 228-265.

Santher, B. 1993. Do cyclopoid copepods control Daphnia population in early spring, thereby protecting their juvenile instar stages from food limitation? Verh. int. Ver. Limnol., 25: 634-637.

Straškrabová, V., C. Callieri, P. Carrillo, L. Cruz-Pizarro, J. Fott, P. Hartman, M. Macek, J.M. Medina-Sánchez, J. Nedoma \& K. Šimek. 1999. Investigations on pelagic food webs in mountain lakes - aims and methods. In: Straškrabová, V., C. Callieri \& J Fott (Eds), Pelagic food web in mountain lakes. MOuntain LAkes Research Program. J. Limnol., 58(2): 77-87.

The MOLAR Water Chemistry Group. 1999. The MOLAR Project: atmospheric deposition and lake water chemistry. In: Straškrabová, V., C. Callieri \& J Fott (Eds), Pelagic food web in mountain lakes. MOuntain LAkes Research Program. J. Limnol., 58(2): 88-106.

Tilzer, M. 1973. Diurnal periodicity in the phytoplankton assemblage of a high mountain lake. Limnol. Oceanogr.,18: 15-30.

Tilzer, M. \& K. Schwartz 1976. Seasonal and vertical patterns of phytoplankton light adaptation in high mountain lake. Arch. Hydrobiol., 77: 488-504.

Tonolli, V. 1949. Gli alti laghi della Val Bognanco. Parte II. Mem. Ist. ital. Idrobiol., 5: 39-93.

Tonolli, V. \& L. Tonolli. 1951. Osservazioni sulla biologia ed ecologia di 170 popolamenti zooplanctonici di laghi alpini d'alta quota. Mem. Ist. ital. Idrobiol., 6: 53-136.

Vijverberg, K. 1989. Culture technique for studies on the growth, development and reproduction of copepods and cladocerans under laboratory and in situ conditions: a review. Freshwat. Biol., 21: 317-373. 